\title{
Intraspecific variation in photosynthetic nitrogen-use efficiency is positively related to photosynthetic rate in rice (Oryza sativa L.) plants
}

\author{
M. YE* ${ }^{*}$ S.B. PENG ${ }^{* * *}$, and Y. $\mathrm{LI}^{*,+}$ \\ Ministry of Agriculture Key Laboratory of Crop Ecophysiology and Farming System in the Middle Reaches of the \\ Yangtze River, College of Plant Science and Technology, Huazhong Agricultural University, Wuhan, Hubei, China* \\ National Key Laboratory of Crop Genetic Improvement, Huazhong Agricultural University, Wuhan, Hubei, China**
}

\begin{abstract}
To explore the natural variation in leaf photosynthesis and investigate its relations with leaf nitrogen (N) status, 121 rice cultivars were pot-grown and their leaf photosynthetic rate $\left(P_{\mathrm{N}}\right)$ and $\mathrm{N}$ content were measured on the flag leaves at heading stage before anthesis. The results showed that there were substantial natural variations in $P_{\mathrm{N}}$, leaf N content based on leaf area and leaf mass, and photosynthetic N-use efficiency (PNUE). $P_{\mathrm{N}}$ ranged between 15.4 and $32.6 \mu \mathrm{mol} \mathrm{m}^{-2} \mathrm{~s}^{-1} ; P_{\mathrm{N}}$ and PNUE of four widely grown cultivars in China were significantly lower than $P_{\mathrm{N}}$ and PNUE of the cultivar Nancay PA, which possessed the highest values for $P_{\mathrm{N}}$ and PNUE. Moreover, PNUE was positively related to $P_{\mathrm{N}}$ across cultivars, the high PNUE was related to high stomatal conductance, high transpiration, and low leaf mass per area. We concluded that intraspecific variation in PNUE is positively related to $P_{\mathrm{N}}$ in rice plants.
\end{abstract}

Additional key words: $\mathrm{CO}_{2}$ diffusion conductance; leaf anatomy; leaf hydraulic conductance.

\section{Introduction}

Improvements in crop management and genetic gain in harvest index lead to a dramatic increase in crop yields, which have more than doubled since 1960 (Long et al. 2015). Although the yields continue to increase in most growing areas on a global scale, the yield improvements are stagnating or even moving in reverse at about $24-39 \%$ of the growing areas for maize, rice, wheat, and soybean crops (Ray et al. 2012, Long 2014). Ray et al. (2013) found that the global yields of these four major crops are now increasing at a rate of 1.6, 1.0, 0.9, and 1.3\% per year, respectively, which is far less than the rate of $2.4 \%$ per year required to double global production by 2050 . Therefore, a second Green Revolution is needed to boost crop production and to meet the rising demand.

Over the past 50 years, intercepted radiation and the harvest index have been largely improved, but the conversion efficiency of visible solar energy, which is related to photosynthesis and respiratory loss, has not been improved (Long et al. 2015). Thus, increasing energy conversion efficiency can promote the yield.
Many researches have aimed to select genotypes for high photosynthesis and were successful in identifying such cultivars (Moss and Musgrave 1971, Austin et al. 1982, Shibles et al. 1987), but most of these cultivars could not reach the higher crop yield (Moss and Musgrave 1971, Ford et al. 1983). The main reason is the complexity of relations between instantaneous assimilation rate of a single leaf and the biomass/yield at the level of a crop canopy. The yield formation is a complex process, the relationship between yield and photosynthesis of a single leaf may be influenced by many factors, such as respiration rate, transportation, etc. In addition, Sinclair et al. (2004) illustrated that the impact of factors that underlie crop yield can be diminished when scaling up to a higher level, e.g., a 50\% increase in mRNA synthesis for Rubisco carboxylase finally increases (or even decreases) yield by up to $6 \%$ depending on the level of nitrogen accumulation. Therefore, though many previous researches showed weak relations between the yield and net photosynthetic rate $\left(P_{\mathrm{N}}\right)$, improving $P_{\mathrm{N}}$ and ascertaining its mechanism is necessary for future breeding work.

$\overline{\text { Received }} 23$ November 2017, accepted 14 June 2018.

${ }^{+}$Corresponding author; e-mail: liyong@mail.hzau.edu.cn

Abbreviations: $E$ - leaf transpiration rate; EFM - evaporative flux method; $f_{\text {ias }}$ - fraction of intercellular air space; $g_{\mathrm{m}}-$ mesophyll conductance to $\mathrm{CO}_{2} ; g_{\mathrm{s}}$ - stomatal conductance to $\mathrm{H}_{2} \mathrm{O} ; \mathrm{HPFM}$ - high pressure flowmeter method; $K_{\text {leaf }}$ - leaf hydraulic conductance; $K_{\mathrm{ox}}$ - out-of-xylem hydraulic conductance; $K_{\mathrm{x}}$ - leaf hydraulic conductance inside xylem; LES - leaf economic spectrum; LMA - leaf mass per area; $\mathrm{N}_{\text {area }}$ - leaf nitrogen content based on leaf area; $\mathrm{N}_{\text {mass }}-$ leaf nitrogen content based on leaf mass; $P_{\mathrm{N}}-$ net photosynthetic rate; PNUE - photosynthetic nitrogen-use efficiency; RKM - rehydration kinetics method; $S_{\mathrm{c}}$ - surface area of chloroplasts exposed to intercellular airspaces per leaf area; $S_{\mathrm{m}}$ - mesophyll cell wall surface area exposed to intercellular airspace per leaf area; SSNM - sitespecific nitrogen management; VPM - vacuum pump method.

Acknowledgements: This work was supported by the National Key Research and Development Program of China (2016YFD0300102), the Foundation for the Author of National Excellent Doctoral Dissertation of China (201465), The Earmarked Fund for China Agriculture Research System (CARS-01-20), and Fundamental Research Funds for the Central Universities (2662017JC002). We thank Danny Tholen (University of Natural Resources and Life Sciences, Vienna, Austria) for his comments on a previous version of this manuscript. 
There are many approaches to enhance $P_{\mathrm{N}}$, for example, designing more efficient Rubisco, increasing mesophyll conductance $\left(g_{\mathrm{m}}\right)$, and introducing the $\mathrm{C}_{4}$ photosynthetic pathway into $C_{3}$ crops (Long et al. 2006). Suzuki et al. (2007) have increased the Rubisco content in rice leaves using transgenic methods, but it failed to enhance $P_{\mathrm{N}}$ due to the changes in $\mathrm{N}$ distribution. Introduction of $\mathrm{C}_{4}$ photosynthetic pathway into $\mathrm{C}_{3}$ crops seems to be an attractive and promising way to increase $P_{\mathrm{N}}$, however, it can take several decades to achieve this ambitious aim due to difficulties in changing leaf anatomy (as $\mathrm{C}_{4}$ plants have special Kranz anatomy) and the complex biochemical actions. Therefore, other strategies should be considered to increase $P_{\mathrm{N}}$ at present.

In addition to these genetic approaches, exploiting natural variation in leaf photosynthesis can also contribute to increasing crop productivity, e.g., rice production $(\mathrm{Gu}$ et al. 2014). Using the crop model GECROS (Yin and van Laar 2005), Gu et al. (2014) showed that improving $P_{\mathrm{N}}$ by exploiting its genetic variation in rice plants can effectively increase biomass production, it shows that an increase in $P_{\mathrm{N}}$ by $25 \%$ can lead to an increase in biomass production of 22-29\%. Natural genetic variation is the fuel of evolution, and is a prerequisite for natural or artificial selection (Flood et al. 2011). However, the natural variation in crop photosynthesis has not been fully studied and exploited, as most studies on photosynthesis are conducted with a few varieties (Cook and Evans 1983, Sasaki and Ishii 1992, Yeo et al. 1994, Giuliani et al. 2013, Xiong et al. 2017). Driever et al. (2014) showed a large variation of $P_{\mathrm{N}}$ between 20.5 and $31.5 \mu \mathrm{mol} \mathrm{m} \mathrm{m}^{-2} \mathrm{~s}^{-1}$ in 64 wheat cultivars. Using 24 rice and wild relatives, Giuliani et al. (2013) explored the variations of leaf structure and its relations with photosynthesis and transpiration. In addition, Xiong et al. (2017) revealed that leaf anatomy can affect both out-of-xylem hydraulic conductance $\left(K_{\mathrm{ox}}\right)$ and the mesophyll $\mathrm{CO}_{2}$ diffusing rate by using 11 Oryza genotypes. But studies on the distribution of $P_{\mathrm{N}}$ among widely grown rice cultivars and its relations with leaf $\mathrm{N}$ content are lacking. It is not known how large potential still exists for improving photosynthesis in widely grown rice cultivars.

$P_{\mathrm{N}}$ is commonly observed to be positively related to the leaf $\mathrm{N}$ content per area $\left(\mathrm{N}_{\text {area }}\right)$, because up to $27 \%$ of the total leaf $\mathrm{N}$ content is invested into Rubisco (Evans 1989, Makino et al. 1997). This suggests that the natural variation in leaf photosynthesis is related to Rubisco and leaf $\mathrm{N}$ content (Driever et al. 2014), and more leaf $\mathrm{N}$ and Rubisco may be required for cultivars possessing a high photosynthetic capacity. Engineering plants with more efficient Rubisco or the introduction of the $\mathrm{C}_{4}$ photosynthetic pathway into $\mathrm{C}_{3}$ crops can simultaneously improve $P_{\mathrm{N}}$ and PNUE (Lin et al. 2014, Carmo-Silva et al. 2015, Long 2015), a major component of N-use efficiency, defined as a ratio of $P_{\mathrm{N}}$ to $\mathrm{N}_{\text {area }}$. However, it is not known whether intraspecific variation in PNUE is related to $P_{\mathrm{N}}$.

In addition to the leaf $\mathrm{N}$ content, there are many other factors that can substantially affect photosynthesis in $\mathrm{C}_{3}$ plants. According to FvCB (Farquhar et al. 1980) model of leaf photosynthesis, photosynthesis of $\mathrm{C}_{3}$ plants can be affected by one of three factors: (1) activity of Rubisco; (2) ribulose-1,5-bisphosphate (RuBP) regeneration; and (3) release of phosphate during the metabolism of triose phosphate to either starch or sucrose (Farquhar et al. 1980, Sage 1990, Harley et al. 1992, Manter and Kerrigan 2004). Under current ambient conditions [around $400 \mu \mathrm{mol}\left(\mathrm{CO}_{2}\right)$ $\mathrm{mol}^{-1}$ (air)], $\mathrm{CO}_{2}$ diffusion conductance from air to carboxylation site was regarded to be one of the limiting factors for $P_{\mathrm{N}}$ in $\mathrm{C}_{3}$ plants (Li et al. 2009, Yamori et al. 2011, Adachi et al. 2013, Flexas et al. 2012, Evans et al. 2009). $\mathrm{CO}_{2}$ diffusion pathway from atmosphere to chloroplast stroma can be divided into two phases - stomatal diffusion and mesophyll diffusion, the corresponding conductances of these two phases are called stomatal conductance $\left(g_{\mathrm{s}}\right)$ and $g_{\mathrm{m}}$, respectively. The $g_{\mathrm{s}}$ is determined by the stomatal features, especially by stomatal aperture. For the reason that $\mathrm{CO}_{2}$ and $\mathrm{H}_{2} \mathrm{O}$ share a common path to enter and diffuse out the stomata, stomatal aperture is highly correlated with plant hydraulic status, which can be effectively represented by transpiration rate $(E)$ (Brodribb et al. 2007, Giuliani et al. 2013, Nardini et al. 2014). For mesophyll diffusion pathway, $\mathrm{CO}_{2}$ needs to pass through the mesophyll cell to get to the carboxylation site after reaching substomatal cavities (Terashima et al. 2011). Therefore, $g_{\mathrm{m}}$ is greatly determined by leaf anatomy. Leaf mass per area (LMA), the ratio of leaf mass to leaf area, is a parameter which is widely used as a leaf anatomical feature. Many researches have showed that high LMA can result in a low $g_{\mathrm{m}}$ (Hassiotou et al. 2009, 2010; Muir et al. 2014). Therefore, the effects of $g_{\mathrm{s}}, E$, and LMA on $P_{\mathrm{N}}$ and PNUE was investigated to reveal the impacts of $\mathrm{CO}_{2} / \mathrm{H}_{2} \mathrm{O}$ diffusion efficiency and leaf anatomy on photosynthetic capacity in present study.

In present study, a pot experiment was conducted using 121 rice cultivars. $P_{\mathrm{N}}$ and its related physiological parameters, i.e., leaf $\mathrm{N}$ content, were measured on the flag leaves. The objectives were: (1) to study natural variation of leaf photosynthesis in rice plants; (2) to explore the relationship between $P_{\mathrm{N}}$ and leaf $\mathrm{N}$ content across a large group of rice cultivars; (3) to investigate the relationship between $P_{\mathrm{N}}$ and PNUE.

\section{Materials and methods}

Plant materials and $\mathbf{N}$ input: A total of 121 rice cultivars were collected from 13 countries (Table 1S, supplement). After germination on moist filters on 11 May 2014, rice cultivars were transferred to nursery plates. When the seedlings developed in average of three leaves, they were transplanted to 11-L pots with a density of three hills per pot and two seedlings per hill. There were five pots per cultivar and each pot was filled with $10 \mathrm{~kg}$ of soil, phosphorus (P) and potassium $(\mathrm{K})$ were applied as basal fertilizers at an amount of $1.5 \mathrm{~g}$ per pot. $\mathrm{N}$ was applied at the amount of $2 \mathrm{~g}(\mathrm{~N})$ per pot, $40 \%$ of which was applied as a basal fertilizer and next two topdressings of $30 \%$ each were applied at mid-tillering and the heading stages, respectively. Plants were watered daily, and a minimum 2-cm water layer was maintained to avoid drought stress. Pests were intensively controlled using chemical pesticides. The experiment was 
conducted outdoors in Huazhong Agricultural University $\left(114.37^{\circ} \mathrm{E}, 30.48^{\circ} \mathrm{N}\right)$ in Wuhan City, Hubei Province, China. Measurements were conducted at the heading stage before anthesis.

Gas exchange was measured with a portable photosynthesis system (LI-6400XT, LI-COR Inc., Lincoln, NE, USA) on the flag leaves between 09:00 and 16:00 h. Throughout all experiments, PPFD during measurements was set to 1,500 $\mu$ mol(photon) $\mathrm{m}^{-2} \mathrm{~s}^{-1}$ using a red-blue LED artificial light source, with $10 \%$ of blue light. Relative humidity was controlled at $\sim 60 \%$ to minimize the impacts of environmental fluctuation on $g_{\mathrm{s}}$ and $P_{\mathrm{N}}$, which resulted in a relative stable VPD of $1.69 \pm 0.53 \mathrm{kPa}$. $\mathrm{CO}_{2}$ concentration in the leaf chamber was about $393 \pm 13 \mu \mathrm{mol} \mathrm{mol}{ }^{-1}$. Leaf temperature was set to $28^{\circ} \mathrm{C}$. Data were recorded after equilibration to a steady state, about $20 \mathrm{~min}$ after enclosing the leaves in the leaf chamber.

In order to compare photosynthetic characteristics of leaves with a similar developmental age, gas-exchange measurements of each cultivar were conducted immediately after the flag leaves fully expanded. The measurements lasted for $19 \mathrm{~d}$ in July and August, and 5-6 cultivars were typically examined in a single day. The measurements were conducted only on sunny days, during which the radiation intensity, average temperature, and relative humidity were $19.2 \pm 4.6 \mathrm{MJ} \mathrm{m}^{-2} \mathrm{~d}^{-1}, 29.1 \pm 2.4^{\circ} \mathrm{C}$, and $77.0 \pm 5.8 \%$, respectively (Fig. $3 \mathrm{~S}$, supplement). Moreover, the environmental conditions in the leaf chamber were tightly controlled by the gas-exchange instrument, which minimized the variations of gas-exchange parameters caused by different ambient environmental conditions. To minimize the diurnal variation of photosynthesis, the measurements were suspended when significant midday depression occurred.

Leaf $\mathbf{N}$ content measurements: Leaves were detached immediately after the gas-exchange measurements, followed by leaf area measurement using a LI-Cor 3000C (LI-COR Inc., Lincoln, NE, USA) leaf area analyzer. Leaves were then oven-dried at $80^{\circ} \mathrm{C}$ until they achieved a constant mass. Afterwards, leaf dry mass was weighed, and leaf mass per area was calculated as the ratio of leaf dry mass to leaf area. Mass-based leaf photosynthesis

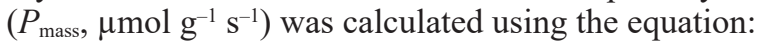

$P_{\text {mass }}=\frac{P_{\mathrm{N}}}{\mathrm{LMA}}$

Leaf equation: Leaf $\mathrm{N}$ content based on leaf mass $\left(\mathrm{N}_{\text {mass }}\right)$ was measured with an Elementar Vario MAX CN analyzer (Elementar Analysesysteme GmbH, Hanau, Germany), and $\mathrm{N}_{\text {area }}$ was calculated by multiplying $\mathrm{N}_{\text {mass }}$ with LMA. PNUE was calculated using the equation:

$\mathrm{PNUE}=\frac{P_{\mathrm{N}}}{\mathrm{N}_{\text {area }}}$

Statistical analysis: One-way analysis of variance $(A N O V A)$ was used to assess varietal differences in each parameter using Statistix 9 software (Analytical Software, Tallahassee, Florida, USA). Linear regression analysis was performed to test the correlations between parameters using SigmaPlot 10 (Systat Software Inc., California, USA). The normal distribution tests of the various photosynthesis traits were conducted by One-sample Kolmogorov-Smirnov's test using SPSS 16.0 (SPSS Inc., Chicago, IL, USA).

\section{Results}

$\mathrm{N}_{\text {area }}$ and $\mathrm{N}_{\text {mass }}$ showed great variations among 121 rice cultivars (Fig. 1, Table 1S). $\mathrm{N}_{\text {area }}$ ranged from $0.94 \mathrm{~g} \mathrm{~m}^{-2}$ for cultivar $\mathrm{N} 22$ (NO. 108) to $1.99 \mathrm{~g} \mathrm{~m}^{-2}$ for cultivar Belgioioso (NO. 54), with a mean value of $1.51 \mathrm{~g} \mathrm{~m}^{-2}$. $\mathrm{N}_{\text {mass }}$ ranged from $1.70 \%$ for cultivar Yangdao 6 (NO. 144) to $3.83 \%$ for cultivar PI 282203 (NO. 88), with a mean value of $2.78 \%$. Similarly, $P_{\mathrm{N}}$ was highly variable among the 121 rice cultivars, ranged from $15.5 \mu \mathrm{mol} \mathrm{m} \mathrm{m}^{-2} \mathrm{~s}^{-1}$ for cultivar N22 (NO. 108) to $32.6 \mu \mathrm{mol} \mathrm{m} \mathrm{m}^{-2} \mathrm{~s}^{-1}$ for cultivar Nancay PA (NO. 33), with a mean value of $23.3 \mu \mathrm{mol}$ $\mathrm{m}^{-2} \mathrm{~s}^{-1}$ (Fig. 2A, Table 1S). Differences between cultivars were highly significant. $\mathrm{N}_{\text {area }}$ of the cultivar with the highest $P_{\mathrm{N}}$ (cultivar 33, Nancay PA) was $1.45 \mathrm{~g} \mathrm{~m}^{-2}\left(\mathrm{~N}_{\text {mass }}=2.39 \%\right.$; Fig. 1, Table 1S), which was lower than the mean value of $1.51 \mathrm{~g} \mathrm{~m}^{-2}\left(2.78 \%\right.$ for $\left.\mathrm{N}_{\text {mass }}\right)$. $P_{\mathrm{N}}$ of widely grown rice cultivars in China - Huanghuazhan (NO. 99), Shanyou 63 (NO. 110), Liangyoupeijiu (NO. 107), and Yangliangyou 6 (NO. 118) - were 23.6, 25.0, 25.7, and 26.1 $\mu \mathrm{mol}$ $\mathrm{m}^{-2} \mathrm{~s}^{-1}$, respectively (Fig. 2, Table $1 \mathrm{~S}$ ). These values were slightly $(1.3-12.0 \%)$ higher than the mean value of all the 121 cultivars, but were significantly lower (19.9-27.8\%) than the highest $P_{\mathrm{N}}\left(32.6 \mu \mathrm{mol} \mathrm{m} \mathrm{m}^{-2} \mathrm{~s}^{-1}\right) . \mathrm{N}_{\text {area }}$ of these four cultivars were $1.55,1.56,1.65$, and $1.69 \mathrm{~g} \mathrm{~m}^{-2}$, which were $2.6-11.9 \%$ higher than the mean $\mathrm{N}_{\text {area }}$ of all the cultivars and were $7.9-17.1 \%$ higher than cultivar 33 (Fig. 1, Table $1 \mathrm{~S}) . \mathrm{N}_{\text {mass }}$ were $2.44,2.59,2.99$, and $2.91 \%$, respectively, which were either lower (for cultivars 99 and 107) or higher (for cultivars 110 and 118) than the mean value of $2.78 \%$ in all cultivars. But they were all higher (2.2-24.9\%) than that of the cultivar 33 .

Across all cultivars, $P_{\mathrm{N}}$ was positively related to $\mathrm{N}_{\text {area }}$ (Fig. 3A), but the correlation coefficient was very low $\left(R^{2}=0.18\right) . \mathrm{N}_{\text {area }}$ of $1.4 \mathrm{~g} \mathrm{~m}^{-2}$ is usually used as a threshold, below which $\mathrm{N}$ fertilization is needed in rice plants (Peng et al. 1996). If the correlation between $P_{\mathrm{N}}$ and $\mathrm{N}_{\text {area }}$ was calculated for cultivars with $\mathrm{N}_{\text {area }}>1.4 \mathrm{~g} \mathrm{~m}^{-2}$, no significant correlation was observed $(P=0.1955, n=91)$, while it was significant for cultivars with $\mathrm{N}_{\text {area }}<1.4 \mathrm{~g} \mathrm{~m}^{-2}(P=0.003$, $n=30)$. This suggested variation in $P_{\mathrm{N}}$, when $\mathrm{N}_{\text {area }}>1.4 \mathrm{~g}$ $\mathrm{m}^{-2}$ did not result from differences in $\mathrm{N}_{\text {area }}$ (Table 1).

PNUE was also significantly different between all rice cultivars and ranged from $10.03 \mu \mathrm{mol}\left(\mathrm{CO}_{2}\right) \mathrm{g}^{-1}(\mathrm{~N})$ $\mathrm{s}^{-1}$ for cultivar Banata 35 (NO. 43) to $22.57 \mu \mathrm{mol}\left(\mathrm{CO}_{2}\right)$ $\mathrm{g}^{-1}(\mathrm{~N}) \mathrm{s}^{-1}$ for cultivar Nancay PA (NO. 33) (Fig. 2B). PNUE was negatively related to $\mathrm{N}_{\text {area }}$ across all cultivars (Fig. $3 B$ ). Interestingly, PNUE was positively related to $P_{\mathrm{N}}$ across all cultivars (Fig. 4), and Nancay PA possessed both the highest $P_{\mathrm{N}}$ and PNUE among all cultivars. This suggested that PNUE and $P_{\mathrm{N}}$ can be simultaneously improved by 


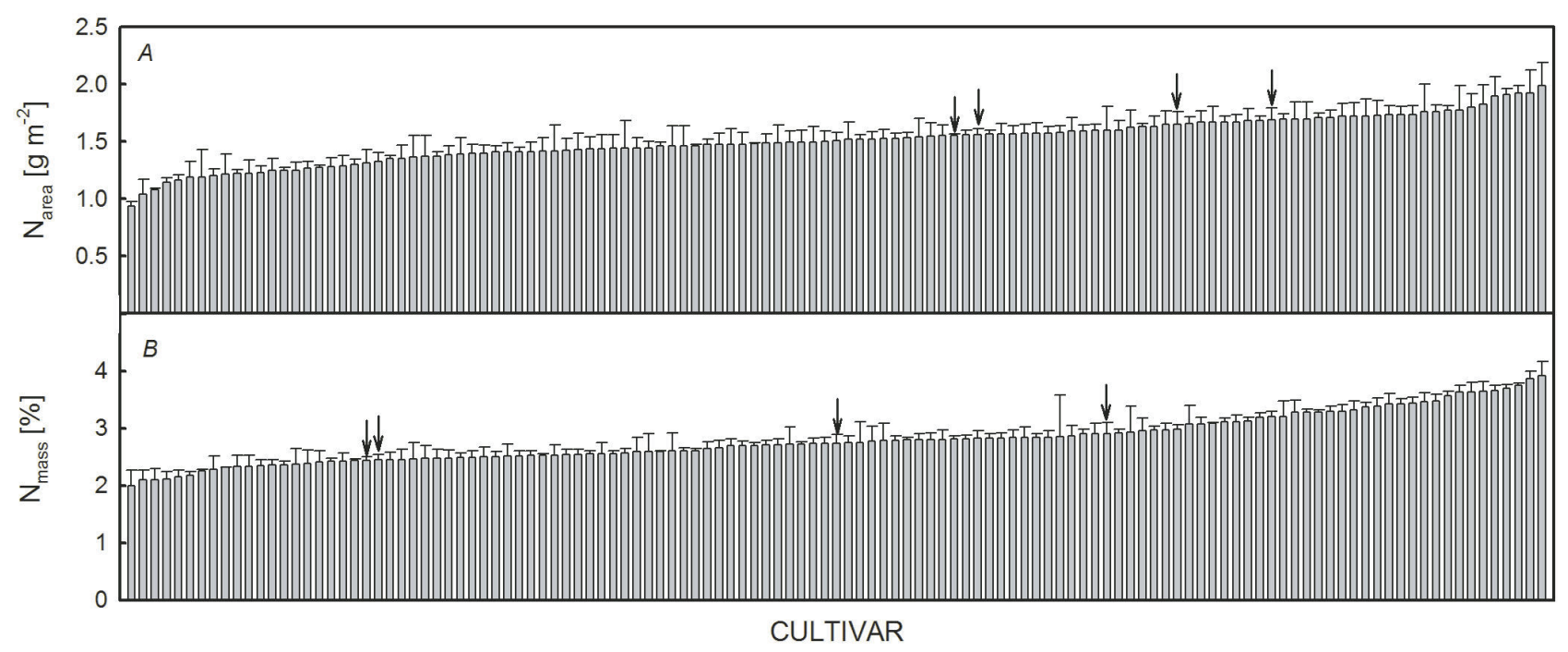

Fig. 1. Natural variations of area based $\left(\mathrm{N}_{\text {area }}\right)$ and mass based $\left(\mathrm{N}_{\text {mass }}\right)$ leaf nitrogen contents of flag leaves among 121 rice cultivars. Cultivars were ranked with the increasing value of each parameter. Arrows indicate the four widely grown cultivars in China, which are Huanghuazhan, Liangyoupeijiu, Shanyou 63, and Yangliangyou 6. Data were shown as means \pm SD of three replications.

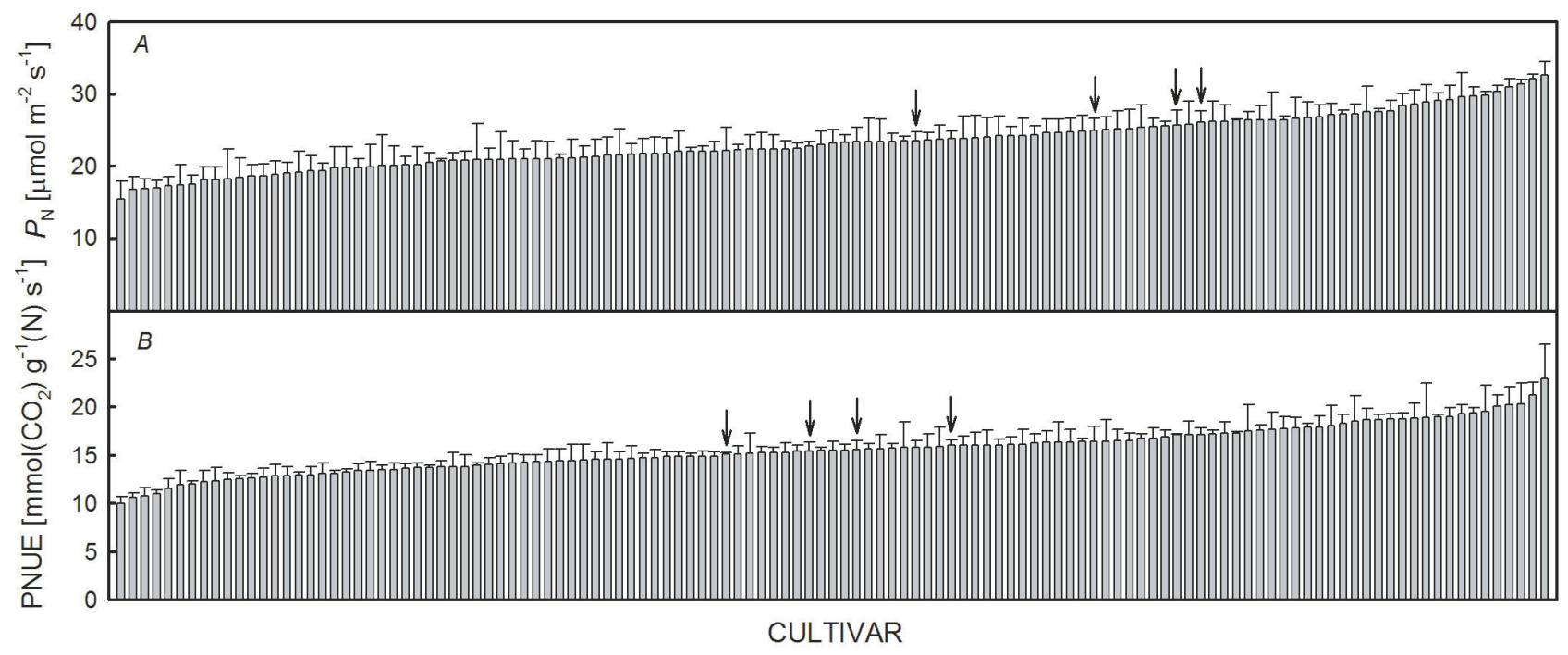

Fig. 2. Natural variations of photosynthetic rate $\left(P_{\mathrm{N}}\right)$ and photosynthetic nitrogen-use efficiency (PNUE) of flag leaves among 121 rice cultivars. Cultivars were ranked with the increasing value of each parameter. Arrows indicate the four widely grown cultivars in China, which are Huanghuazhan, Liangyoupeijiu, Shanyou 63, and Yangliangyou 6. Data were shown as means \pm SD of four replications.

Table 1. Mean values of leaf photosynthetic rate $\left(P_{\mathrm{N}}\right)$ and its' respective area based leaf $\mathrm{N}$ content $\left(\mathrm{N}_{\text {area }}\right)$ of the cultivars in four groups. Values represent means $\pm \mathrm{SD}$, different letters indicate statistical differences at $P<0.05$.

\begin{tabular}{llrc}
\hline & $P_{\mathrm{N}}\left[\mu \mathrm{mol} \mathrm{m} \mathrm{m}^{-2} \mathrm{~s}^{-1}\right] \mathrm{N}_{\text {area }}\left[\mathrm{g} \mathrm{m}^{-2}\right]$ & No. of cultivars \\
\hline$P_{\mathrm{N}} \geq 30$ & $31.5 \pm 0.9^{\mathrm{a}}$ & $1.67 \pm 0.17^{\mathrm{a}}$ & 5 \\
$25 \leq P_{\mathrm{N}}<30$ & $27.0 \pm 1.5^{\mathrm{b}}$ & $1.57 \pm 0.16^{\mathrm{a}}$ & 34 \\
$20 \leq P_{\mathrm{N}}<25$ & $22.4 \pm 1.4^{\mathrm{c}}$ & $1.53 \pm 0.18^{\mathrm{a}}$ & 60 \\
$P_{\mathrm{N}}<20$ & $18.4 \pm 1.2^{\mathrm{d}}$ & $1.35 \pm 0.22^{\mathrm{b}}$ & 22 \\
\hline
\end{tabular}

exploiting the natural variation of rice plants at the leaf scale. In comparison, PNUE of the widely grown cultivars $99,107,110$, and 118 were $29.0-32.8 \%$ lower than that of the cultivar 33 .

$g_{\mathrm{s}}$ and $E$ also showed significant varietal differences between all rice cultivars. $g_{\text {s }}$ ranged from $0.22 \mathrm{~mol}\left(\mathrm{H}_{2} \mathrm{O}\right)$ $\mathrm{m}^{-2} \mathrm{~s}^{-1}$ for Elba (NO. 60) to $0.93 \mathrm{~mol}\left(\mathrm{H}_{2} \mathrm{O}\right) \mathrm{m}^{-2} \mathrm{~s}^{-1}$ for Belgioioso (NO. 54), while $E$ ranged from $3.09 \mathrm{mmol}$ $\left(\mathrm{H}_{2} \mathrm{O}\right) \mathrm{m}^{-2} \mathrm{~s}^{-1}$ for Ejingyou 775 (NO. 91) to $13.05 \mathrm{mmol}$ $\left(\mathrm{H}_{2} \mathrm{O}\right) \mathrm{m}^{-2} \mathrm{~s}^{-1}$ for Baek Na (NO. 22). $P_{\mathrm{N}}$ and $E$ both showed significant and positive relationships with $g_{\mathrm{s}}$ (Fig. 5). In addition, PNUE showed positive relationships with both 


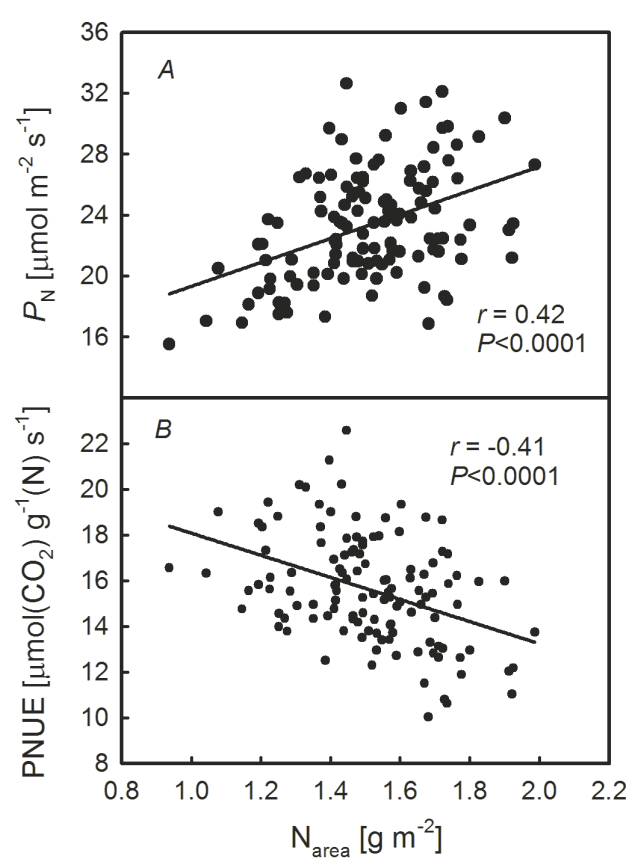

Fig. 3. Correlations of photosynthetic rate $\left(P_{\mathrm{N}}\right)$ and photosynthetic nitrogen-use efficiency (PNUE) with area based leaf nitrogen content $\left(\mathrm{N}_{\text {area }}\right)$ across 121 rice cultivars.

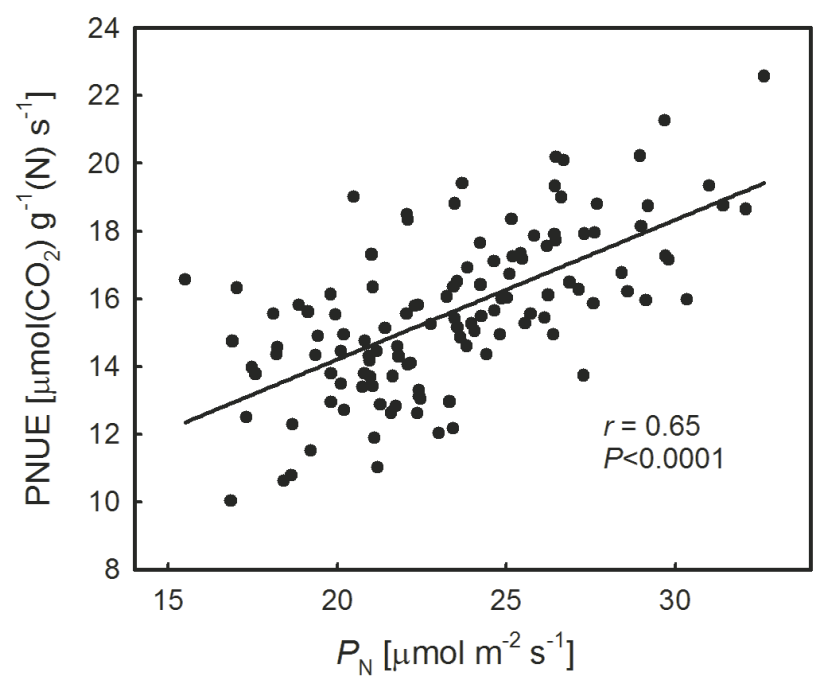

Fig. 4. Relationship between photosynthetic nitrogen-use efficiency $(\mathrm{PNUE})$ and photosynthetic rate $\left(P_{\mathrm{N}}\right)$ across 121 rice cultivars.

$g_{\mathrm{s}}$ and $E$ (Fig. 6).

LMA and $P_{\text {mass }}$ also showed significant differences between all rice cultivars (Supplementary Table 1S). LMA ranged from $38.10 \mathrm{~g} \mathrm{~m}^{-2}$ for $\mathrm{N} 22(\mathrm{NO} .108)$ to $73.30 \mathrm{~g} \mathrm{~m}^{-2}$ for Yongyou 12 (NO. 119), while $P_{\text {mass }}$ ranged from 0.27 $\mu \mathrm{mol} \mathrm{g}{ }^{-1} \mathrm{~s}^{-1}$ for Yangjing 4227 (NO. 115 ) to $0.70 \mu \mathrm{mol}$ $\mathrm{g}^{-1} \mathrm{~s}^{-1}$ for Kirmizi Celtik (NO. 68). Moreover, $\mathrm{N}_{\text {area }}$ was positively related to LMA, and PNUE was negatively related to LMA (Fig. 7).

$\mathrm{N}_{\text {mass }}, \mathrm{N}_{\text {area }}, P_{\mathrm{N}}$, PNUE, $g_{\mathrm{s}}, E, \mathrm{LMA}$, and $P_{\text {mass }}$ were all normally distributed (Fig. 1S, supplement). There were

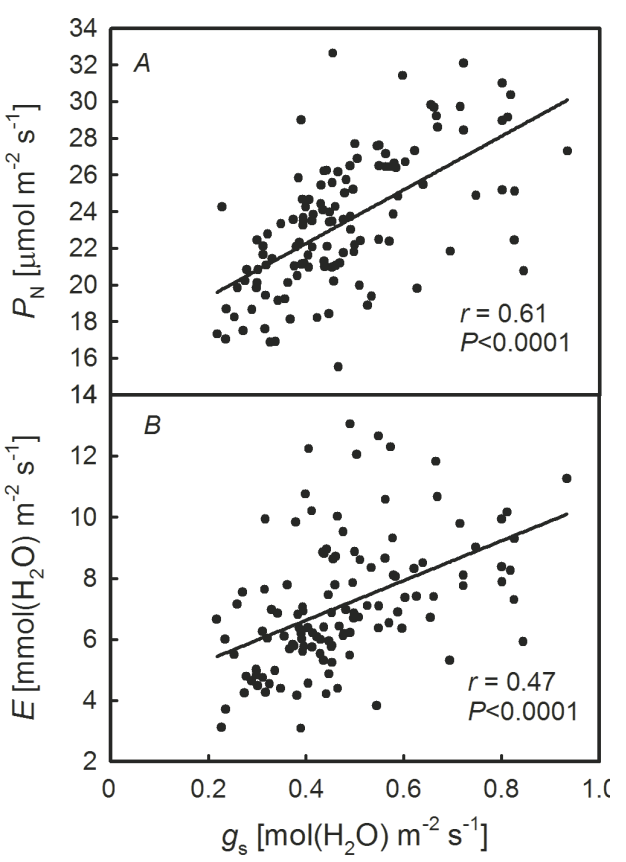

Fig. 5. Correlations of photosynthetic rate $\left(P_{\mathrm{N}}\right)$ and transpiration rate $(E)$ with stomatal conductance $\left(g_{\mathrm{s}}\right)$ across 121 rice cultivars.

83 rice cultivars possessing $\mathrm{N}_{\text {mass }}$ of $2.25-3.0 \%(68.6 \%$ of all cultivars), while 54 rice cultivars showed $\mathrm{N}_{\text {area }}$ of 1.4 $1.6 \mathrm{~g} \mathrm{~m}^{-2}$ (44.6\% of all cultivars). $P_{\mathrm{N}}$ for 80 rice cultivars (accounting for $66.1 \%$ of all cultivars) ranged between 20-27 $\mu \mathrm{mol} \mathrm{m}{ }^{-2} \mathrm{~s}^{-1}$, while PNUE of 86 rice cultivars ranged between $13.0-18.0 \mu \mathrm{mol} \mathrm{g}^{-1}(\mathrm{~N}) \mathrm{s}^{-1}$. There were only five cultivars whose $P_{\mathrm{N}}$ was more than $30 \mu \mathrm{mol} \mathrm{m} \mathrm{m}^{-2} \mathrm{~s}^{-1}$.

\section{Discussion}

In the present study, 121 rice cultivars selected from worldwide were used to investigate the natural variation of leaf photosynthesis. PPFD of $1,500 \mu \mathrm{mol}$ (photon) $\mathrm{m}^{-2} \mathrm{~s}^{-1}$ is a saturating light intensity for rice species according to previous studies (Li et al. 2009, Xiong et al. $2015,2016,2017)$, and is also a typical light intensity in midday during rice growth season at the experimental site. Therefore, this light intensity was used to study the intraspecific variation of photosynthesis in rice species.

The results showed that there was a large natural variation in leaf photosynthesis, ranging from 15.5 to $32.6 \mu \mathrm{mol} \mathrm{m} \mathrm{m}^{-2} \mathrm{~s}^{-1}$. The natural variation in leaf photosynthesis would potentially be larger if more cultivars were selected, especially, when including wild species with photosynthetic rates that range from $14.3 \mu \mathrm{mol}$ $\mathrm{m}^{-2} \mathrm{~s}^{-1}$ for Oryza glumaepatula to $37.6 \mu \mathrm{mol} \mathrm{m} \mathrm{m}^{-2} \mathrm{~s}^{-1}$ for Oryza rufipogon (Zhao et al. 2010).

The yield improvement of the Green Revolution has been achieved largely through improved genetics, better crop management, and protection. Many studies during the period 1970-1980 have selected cultivars with higher photosynthetic rates to improve crop yield (Moss and Musgrave 1971, Ford et al. 1983). In present study, $P_{\mathrm{N}}$ was not related to the year of cultivar release 


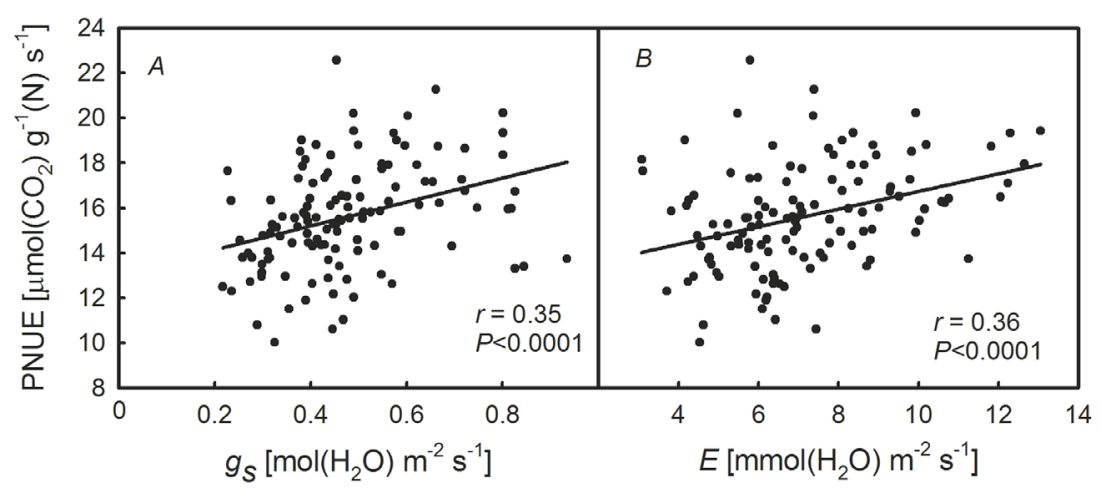

Fig. 6. Correlations of photosynthetic nitrogen-use efficiency (PNUE) with stomatal conductance $\left(g_{\mathrm{s}}\right)$ and transpiration rate $(E)$ across 121 rice cultivars.

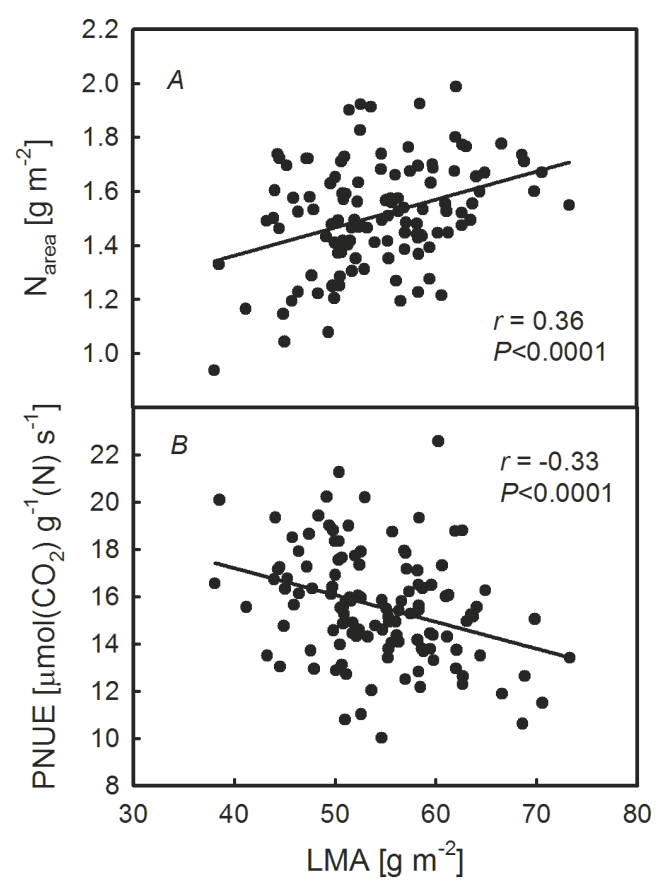

Fig. 7. Correlations of area based leaf nitrogen content $\left(\mathrm{N}_{\text {area }}\right)$ and photosynthetic nitrogen-use efficiency (PNUE) with leaf mass per area (LMA) across 121 rice cultivars.

(Fig. 2S, supplement). $P_{\mathrm{N}}$ of widely grown cultivars, i.e., Huanghuazhan (NO. 99), Liangyoupeijiu (NO. 107), Shanyou 63 (NO. 110), and Yangliangyou 6 (NO. 118) in China, was only slightly $(1.3-12.0 \%)$ higher than the mean value of all the 121 cultivars. By contrast, $P_{\mathrm{N}}$ of the cultivar 33 was $24.9-38.1 \%$ higher than these widely grown cultivars. As we know, widely grown cultivars are widely planted mainly for their high grain yield and strong resistance to stresses. It means that relying on moderate photosynthetic rate can even reach a high yield level in these widely grown cultivars. If kept their advantages in other traits and improve their $P_{\mathrm{N}}$ to $32.6 \mu \mathrm{mol} \mathrm{m}{ }^{-2} \mathrm{~s}^{-1}$ (NO. 33's level) by breeding, their yield might be further increased.

Intensive crop management strategies, such as sitespecific nitrogen management (SSNM) and integrated soil-crop system management, have been developed to realize high-yield crops and high-efficiency production systems. In SSNM, N application is based on leaf $\mathrm{N}$ status measured with a chlorophyll meter or leaf color chart (Peng et al. 2010). According to this system, $\mathrm{N}$ is needed to be applied when $\mathrm{N}_{\text {area }}$ of the topmost fully expanded leaf is lower than $1.4 \mathrm{~g} \mathrm{~m}^{-2}$ (Peng et al. 1996). In the present study, $\mathrm{N}_{\text {area }}$ showed a large variation from 0.94 to $1.99 \mathrm{~g} \mathrm{~m}^{-2}$ among the tested cultivars, and $\mathrm{N}_{\text {area }}$ in 91 out of 121 rice cultivars (accounting for $75.2 \%$ ) was higher than this threshold (Table 1S). But it should be noted that $\mathrm{N}_{\text {area }}$ in pot experiments is related to pot size and plant biomass (Poorter et al. 2012), and cultivars with high biomass accumulation are more limited by $\mathrm{N}$ supply. Further research should be conducted to investigate the response of photosynthesis to $\mathrm{N}$ supplies in these cultivars.

In the present study, $\mathrm{N}_{\text {area }}$ of $1.4 \mathrm{~g} \mathrm{~m}^{-2}$ was enough for some cultivars to achieve a high $P_{\mathrm{N}}$ of about $30 \mu \mathrm{mol} \mathrm{m}^{-2} \mathrm{~s}^{-1}$, i.e., cultivar 33 and 38 achieved very high photosynthetic rates of 32.6 and $29.7 \mu \mathrm{mol} \mathrm{m} \mathrm{m}^{-2} \mathrm{~s}^{-1}$, with $\mathrm{N}_{\text {area }}$ of 1.45 and $1.40 \mathrm{~g} \mathrm{~m}^{-2}$, respectively. This suggested that improving photosynthesis in rice plants did not necessarily require more $\mathrm{N}$ input at the leaf scale. PNUE and $P_{\mathrm{N}}$ was found to be positively related, which is an interesting finding. If PNUE and $P_{\mathrm{N}}$ of widely grown cultivars can be improved to the level of the cultivar 33 through a conventional breeding approach, we can potentially produce more rice grains with less $\mathrm{N}$ input.

In addition to leaf $\mathrm{N}$ content, $\mathrm{CO}_{2}$ diffusion conductance is one of the limiting factors to $P_{\mathrm{N}}$ under current ambient conditions, and $g_{\mathrm{s}}$ is highly correlated with plant hydraulic status and $E$. In present study, $P_{\mathrm{N}}, E$, and PNUE showed significant relationships with $g_{\mathrm{s}}$, and PNUE was also positively related to $E$. This suggested that high hydraulic transport efficiency enhances the stomatal $\mathrm{CO}_{2}$ diffusion, and finally contributes to a high PNUE. Giuliani et al. (2013) illustrated that there was a coordination between photosynthesis, transpiration, and structural traits in rice and wild relatives. Xiong et al. (2015) showed the proportion of minor vein length has a great effect on leaf hydraulic conductance $\left(K_{\text {leaf }}\right)$ in rice. In addition, Xiong et al. (2017) have divided $K_{\text {leaf }}$ into two parts - leaf hydraulic conductance inside xylem $\left(K_{\mathrm{x}}\right)$ and $K_{\mathrm{ox}}$ to investigate the effects of leaf morphological and anatomical traits on leaf hydraulic conductances and $\mathrm{CO}_{2}$ diffusion conductance. And they suggested that the relationship between $K_{\text {ox }}$ and $g_{\mathrm{m}}$ is coordinated by leaf anatomy, including the fraction of intercellular airspace $\left(f_{\text {ias }}\right)$, mesophyll cell wall thickness, mesophyll cell wall surface area exposed to intercellular airspace per leaf area $\left(S_{\mathrm{m}}\right)$, and surface area of chloroplasts 
exposed to intercellular airspace $\left(S_{\mathrm{c}}\right)$. However, there are some problems for $\mathrm{Kx}$ and Kox because they are difficult to be directly and accurately measured, although several approaches (including the evaporative flux method (EFM), the rehydration kinetics method (RKM), the high pressure flowmeter method (HPFM), and the vacuum pump method (VPM)) for determining $K_{\text {leaf }}$ have been developed (Flexas et al. 2013, Xiong et al. 2017). After diffusing out of leaf veins in liquid phase, water should evaporate through existing stomata as water vapor (Rockwell et al. 2014). Where does the evaporation occur is unkown, although Rockwell et al. (2014) reported that it mainly occurred at the vascular bundles and peristomatal regions in red oak (Quercus rubra) trees. Moreover, environmental variations may have some impact on $K_{\mathrm{ox}}$. Environmental conditions surrounding leaves can effectively influence the liquid and vapor phases in the outside-xylem regions. For example, Buckley et al. (2015) predicted that vapor-phase can contribute up to $39.2-44 \%$ of $K_{\text {ox }}$ when temperature gradient between vascular plain and the epidermis is $0.2 \mathrm{~K}$. It suggested that temperature can strongly affect the liquid and vapor status inside leaves. Therefore, it is necessary to develop direct and more accurate methods for $K_{\mathrm{x}}$ and $K_{\mathrm{ox}}$ measurements, and to study their responses to environmental changes, such as temperature and light intensity.

LMA is an important leaf structural trait, which can substantially affect leaf photosynthesis and plant growth. The dry mass of a leaf consists of a wide range of components, which can be divided into eight different classes, including structural carbohydrates, lignin, and minerals among others (Poorter et al. 2009). As one of the most important minerals, $\mathrm{N}$ content per leaf area was thus observed to be increased in high-LMA leaves (Hikosaka and Shigeno 2009), and a similar result was observed in present study (Fig. 7A). Moreover, PNUE was shown to be negatively related to LMA (Fig. 7B), which was consistent with previous studies (Takashima et al. 2004, Hikosaka and Shigeno 2009). This suggested that leaf anatomy can substantially affect leaf photosynthesis and PNUE. For mesophyll diffusion pathway, after diffusing through stomata, $\mathrm{CO}_{2}$ needs to pass through the cell wall, cell membrane, cytoplasm, chloroplast envelope, and stroma to reach carboxylation sites. Thus, $g_{\mathrm{m}}$ is greatly determined by leaf anatomy, such as the fraction of intercellular air space $\left(f_{\text {ias }}\right), S_{\mathrm{m}}, S_{\mathrm{c}}$, and cell wall thickness (Evans et al. 2009, Scafaro et al. 2011, Terashima et al. 2011, Peguero-Pina et al. 2012, Tosens et al. 2012, Giuliani et al. 2013, Tomás et al. 2013, Muir et al. 2014). Generally, leaves possessing the high LMA usually have thicker cell wall, smaller intercellular air spaces (low $f_{\text {ias }}, S_{\mathrm{m}}, S_{\mathrm{c}}$ ) and relatively lower $g_{\mathrm{m}}$ and PNUE (Terashima et al. 2006, Tosens et al. 2012, Onoda et al. 2017). In addition, leaves possessing different LMA also have different $\mathrm{N}$ distribution. Onoda et al. (2017) have investigated physiological and structural tradeoffs underlying the leaf economics spectrum (LES) by analyzing a novel data compilation. It demonstrated that leaves with the high LMA, and a greater fraction of leaf dry mass in cell wall typically have a lower fraction of $\mathrm{N}$ in photosynthetic proteins, and thus low $\mathrm{CO}_{2}$-diffusion rates. More research should be conducted to explore the $\mathrm{N}$ allocation in leaves with different LMA and its effects on PNUE.

Conclusions: The current study revealed that there are substantial natural variations in $P_{\mathrm{N}}, \mathrm{N}_{\text {area }}, \mathrm{N}_{\text {mass }}$, and PNUE, and a large potential still exists to improve $P_{\mathrm{N}}$ and PNUE in widely grown rice cultivars. $P_{\mathrm{N}}$ and PNUE for four widely grown rice cultivars were $19.9-27.8 \%$ and $29.0-32.8 \%$ lower than the cultivar 33 (Nancay PA). $\mathrm{N}_{\text {area }}$ of $1.4 \mathrm{~g} \mathrm{~m}^{-2}$ was enough for some cultivars to achieve high photosynthesis of $30 \mu \mathrm{mol} \mathrm{m} \mathrm{m}^{-2} \mathrm{~s}^{-1}$. PNUE showed a positive relationship with $P_{\mathrm{N}}$ across the 121 rice cultivars, and the high PNUE was associated with the high $g_{\mathrm{s}}, E$, and low LMA.

\section{References}

Adachi S., Nakae T., Uchida M. et al.: The mesophyll anatomy enhancing $\mathrm{CO}_{2}$ diffusion is a key trait for improving rice photosynthesis. - J. Exp. Bot. 64: 1061-1072, 2013.

Austin R.B., Morgan C.L., Ford M.A. et al.: Flag leaf photosynthesis of Triticum aestivum and related diploid and tetraploid species. - Ann. Bot.-London 49: 177-189, 1982.

Brodribb T.J., Field T.S., Jordan G.J. et al.: Leaf maximum photosynthetic rate and venation are linked by hydraulics. Plant Physiol. 144: 1890-1898, 2007.

Buckley T.N., John G.P., Scoffoni C. et al.: How does leaf anatomy influence water transport outside the xylem? - Plant Physiol. 168: 1616-35, 2015.

Carmo-Silva E., Scales J.C., Madgwick P.J. et al.: Optimizing Rubisco and its regulation for greater resource use efficiency. - Plant Cell Environ. 38: 1817-1832, 2015.

Cook M.G., Evans L.T.: Some physiological aspects of the domestication and improvement of rice (Oryza spp.). - Field Crop. Res. 6: 219-238, 1983.

Driever S.M., Lawson T., Andralojc P.J. et al.: Natural variation in photosynthetic capacity, growth, and yield in 64 fieldgrown wheat genotypes. - J. Exp. Bot. 65: 4959-4973, 2014.

Evans J.R.: Photosynthesis and nitrogen relationship in leaves of C3 plants. - Oecologia 78: 9-19, 1989.

Evans J.R., Kaldenhoff R., Genty B. et al.: Resistances along the $\mathrm{CO}_{2}$ diffusion pathway inside leaves. - J. Exp. Bot. 60: 22352248, 2009.

Farquhar G.D, von Caemmerer S., Berry J.A.: A biochemical model of photosynthetic $\mathrm{CO}_{2}$ assimilation in leaves of $\mathrm{C}_{3}$ species. - Planta 149: 78-90, 1980.

Flexas J., Barbour M.M., Brendel O. et al.: Mesophyll diffusion conductance to $\mathrm{CO}_{2}$ : an unappreciated central player in photosynthesis. - Plant Sci. 193-194: 70-84, 2012.

Flexas J., Scoffoni C., Gago J. et al.: Leaf mesophyll conductance and leaf hydraulic conductance: an introduction to their measurement and coordination. - J. Exp. Bot. 64: 3965-3981, 2013.

Flood P.J., Harbinson J., Aarts M.G.M.: Natural genetic variation in plant photosynthesis. - Trends Plant Sci. 16: 327-335, 2011.

Ford D.M., Shibles R., Green D.E.: Growth and yield of soybean lines selected for divergent leaf photosynthetic ability. - Crop Sci. 23: 517-520, 1983.

Giuliani R., Koteyeva N., Voznesenskaya E. et al.: Coordination of leaf photosynthesis, transpiration, and structural traits in rice and wild relatives (genus Oryza). - Plant Physiol. 162: 1632-1651, 2013

Gu J.F., Yin X., Stomph T.J., Struik P.C.: Can exploiting 
natural genetic variation in leaf photosynthesis contribute to increasing rice productivity? A simulation analysis. - Plant Cell Environ. 37: 22-34, 2014.

Harley P.C., Loreto F., Di Marco G. et al.: Theoretical considerations when estimating the mesophyll conductance to $\mathrm{CO}_{2}$ flux by analysis of the response of photosynthesis to $\mathrm{CO}_{2}$. Plant Physiol. 98: 1429-1436, 1992.

Hassiotou F., Ludwig M., Renton M. et al.: Influence of leaf dry mass per area, $\mathrm{CO}_{2}$, and irradiance on mesophyll conductance in sclerophylls. - J. Exp. Bot. 60: 2303-2314, 2009.

Hassiotou F., Renton M., Ludwig M. et al.: Photosynthesis at an extreme end of the leaf trait spectrum: how does it relate to high leaf dry mass per area and associated structural parameters? - J. Exp. Bot. 61: 3015-3028, 2010.

Hikosaka K., Shigeno A.: The role of Rubisco and cell walls in the interspecific variation in photosynthetic capacity. Oecologia 160: 443-451, 2009.

Li Y., Gao Y.X., Xu X.M. et al.: Light-saturated photosynthetic rate in high-nitrogen rice (Oryza sativa L.) leaves is related to chloroplastic $\mathrm{CO}_{2}$ concentration. - J. Exp. Bot. 60: 23512360, 2009.

Lin M.T., Occhialini A., Andralojc P.J. et al.: A faster Rubisco with potential to increase photosynthesis in crops. - Nature 513: 547-552, 2014.

Long S.P., Marshall-Colon A., Zhu X.G.: Meeting the global food demand of the future by engineering crop photosynthesis and yield potential. - Cell 161: 56-66, 2015.

Long S.P., Zhu X.G., Naidu S.L. et al.: Can improvement in photosynthesis increase crop yields? - Plant Cell Environ. 29: 315-330, 2006

Long S.P.: We need winners in the race to increase photosynthesis in rice, whether from conventional breeding, biotechnology or both. - Plant Cell Environ. 37: 19-21, 2014.

Makino A., Shimada T., Takumi S. et al.: Does decrease in ribulose-1, 5-bisphosphate carboxylase by antisense $R b c S$ lead to a higher N-use efficiency of photosynthesis under conditions of saturating $\mathrm{CO}_{2}$ and light in rice plants? - Plant Physiol. 114: 483-491, 1997.

Manter D.K., Kerrigan J.: $A / \mathrm{C}_{\mathrm{i}}$ curve analysis across a range of woody plant species: influence of regression analysis parameters and mesophyll conductance. - J. Exp. Bot. 55: 2581-2588, 2004.

Moss D.N. Musgrave R.B.: Photosynthesis and crop production. - Adv. Agronom. 23: 317-336, 1971.

Muir C.D., Hangarter R.P., Moyle L.C. et al.: Morphological and anatomical determinants of mesophyll conductance in wild relatives of tomato (Solanum sect. Lycopersicon, sect. Lycopersicoides; Solanaceae). - J. Exp. Bot. 37: 1415-1426, 2014.

Nardini A., Õunapuu-Pikas E., Savi T. et al.: When smaller is better: leaf hydraulic conductance and drought vulnerability correlate to leaf size and venation density across four Coffea arabica genotypes. - Funct. Plant Biol. 41: 972-982, 2014.

Onoda Y., Wright I.J., Evans J.R. et al.: Physiological and structural tradeoffs underlying the leaf economics spectrum. - New Phytol. 214: 1447-1463, 2017.

Peguero-Pina J.J., Flexas J., Galmés J. et al.: Leaf anatomical properties in relation to differences in mesophyll conductance to $\mathrm{CO}_{2}$ and photosynthesis in two related Mediterranean Abies species. - Plant Cell Environ. 35: 2121-2129, 2012.

Peng S.B., Buresh R.J, Huang J.L. et al.: Improving nitrogen fertilization in rice by site-specific $\mathrm{N}$ management. A review. - Agron. Sustain. Dev. 30: 649-656, 2010.

Peng S.B., Garcia F.V., Laza R. C. et al:: Increased N-use efficiency using a chlorophyll meter on high-yielding irrigated rice. - Field Crops Res. 47: 243-252, 1996.
Poorter H., Bühler J., van Dusschoten, et al.: Pot size matters: a meta-analysis of the effects of rooting volume on plant growth. - Funct. Plant Biol. 39: 839-850, 2012.

Poorter H., Niinemets U., Poorter L. et al.: Causes and consequences of variation in leaf mass per area (LMA): a meta-analysis. - New Phytol. 182: 565-588, 2009.

Ray D.K., Mueller N.D., West P.C. et al.: Yield trends are insufficient to double global crop production by 2050. - PLoS ONE 8: e66428, 2013.

Ray D.K., Ramankutty N., Mueller N.D. et al.: Recent patterns of crop yield growth and stagnation. - Nat. Commun. 3: 1293, 2012.

Rockwell F.E., Holbrook N.M., Stroock A.D.: The competition between liquid and vapor transport in transpiring leaves. Plant Physiol. 164: 1741-1758, 2014.

Sasaki H., Ishii R.: Cultivar differences in photosynthesis or cie bred in Japan. - Photosynth. Res. 32: 139-146, 1992.

Sage R.F.: A model describing the regulation of ribulose-1,5bisphosphate carboxylase, electron transport, and triose phosphate use in response to light intensity and $\mathrm{CO}_{2}$ in $\mathrm{C}_{3}$ plants. - Plant Physiol. 94: 1728-1734, 1990.

Scafaro A.P., von Caemmerer S., Evans J.R. et al.: Temperature response of mesophyll conductance in cultivated and wild Oryza species with contrasting mesophyll cell wall thickness. - Plant Cell Environ. 34: 1999-2008, 2011.

Shibles R., Secor J., Ford D.M.: Carbon assimilation and metabolism. - In: Wilcox J.R. (ed.): Soybeans: Improvement, Production, and Uses, $2^{\text {nd }}$ ed. Pp. 535-588. Am. Soc. Agron., Madison 1987.

Sinclair T.R., Purcell L.C., Sneller C.H.: Crop transformation and the challenge to increase yield potential. - Trends Plant Sci. 9: 70-75, 2004.

Suzuki Y., Ohkubo M., Hatakeyama H. et al.: Increased Rubisco content in transgenic rice transformed with the 'sense' $r b c S$ gene. - Plant Cell Physiol. 48: 626-637, 2007.

Takashima T., Hikosaka K., Hirose T.: Photosynthesis or persistence: nitrogen allocation in leaves of evergreen and deciduous Quercus species. - Plant Cell Environ. 27: 10471054, 2004.

Terashima I., Hanba Y.T., Tholen D. et al.: Leaf functional anatomy in relation to photosynthesis. - Plant Physiol. 155: 108-116, 2011.

Tomás M., Flexas J., Copolovici L. et al.: Importance of leaf anatomy in determining mesophyll diffusion conductance to $\mathrm{CO}_{2}$, across species: quantitative limitations and scaling up by models. - J. Exp. Bot. 64: 2269, 2013.

Tosens T., Niinemets U., Westoby M. et al.: Anatomical basis of variation in mesophyll resistance in eastern Australian sclerophylls: News of a long and winding path. - J. Exp. Bot. 63: 5105-5119, 2012.

Xiong D., Liu X., Liu L. et al:: Rapid responses of mesophyll conductance to changes of $\mathrm{CO}_{2}$ concentration, temperature and irradiance are affected by $\mathrm{N}$ supplements in rice. - Plant Cell Environ. 38: 2541-2550, 2016.

Xiong D., Yu T., Zhang T. et al.: Leaf hydraulic conductance is coordinated with leaf morpho-anatomical traits and nitrogen status in the genus Oryza. - J. Exp. Bot. 66: 741-748, 2015.

Xiong D., Flexas J., Yu T. et al.: Leaf anatomy mediates coordination of leaf hydraulic conductance and mesophyll conductance to $\mathrm{CO}_{2}$ in Oryza. - New Phytol. 213: 572-583, 2017.

Yamori W., Nagai T., Makino A.: The rate-limiting step for $\mathrm{CO}_{2}$ assimilation at different temperatures is influenced by the leaf nitrogen content in several $\mathrm{C}_{3}$ crop species. - Plant Cell Environ. 34: 764-777, 2011.

Yeo M.E., Yeo A.R., Flowers T.J.: Photosynthesis and photorespi- 
ration in the genus Oryza. - J. Exp. Bot. 45: 553-560, 1994.

Yin X., van Laar H., Yin X. et al.: Crop systems dynamics: an ecophysiological simulation model for genotype-byenvironment interactions. Wagningen Academic Publishers,
Wageningen 2005.

Zhao M., Ding Z., Lafitte R. et al.: Photosynthetic characteristics in Oryza species. - Photosynthetica 48: 234-240, 2010.

(C) The authors. This is an open access article distributed under the terms of the Creative Commons BY-NC-ND Licence. 